\author{
Chaikovska 0 . \\ Stolyarchuk I.
}

\title{
ANALYSIS OF E-DOCUMENT MANAGEMENT SYSTEMS IN UKRAINE AND CRITERIA FOR THEIR SELECTION
}

Об'єктом дослідження є критерії вибору системи електронного документообігу (СЕД) на IT-ринку України та життєвий цикл управлінського рімення в СЕД. Одним з найбільи проблемних місиь є відсутність системних досліджень стосовно стану та особливостей впровадження систем автоматизації документообігу в Україні. Данні про обсяги ринку та перспективи розвитку приблизні і визначаються на підставі оцінок самих учасників ринку. В таких умовах вибір програмного забезпечення для ведення електронного документообігу стає складною задачею. Сучасний процесний підхід в СЕД зобов'язує замовника чітко представляти сутність процесів автоматизації. Вагомим фактором, що впливає на успіх проектів впровадження е-документообігу, стає необхідність формалізації базових процесів.

В процесі дослідження використовувалися наступні методи: бібліографічний, монографічний, порівняльний та синтетично-аналітичний, метод логічного узагальнення та систематизацї̈, алгоритмічний з графічним представленням результатів.

В роботі проведено комплексний аналіз особливостей впровадження та актуальних тенденцій розвитку світових та українських систем електронного документообігу. 3 урахуванням иих особливостей та трендів сформована система ефективних критеріїв оцінювання програмного забезпечення для автоматизації українського документообігу. Критерії розбити на групи, які відповідають етапам життєвого ииклу автоматизованої системи і вимогам сучасного IT-ринку.

Розроблена система критеріїв надає можливість підприємству-замовнику здійснити оптимальний вибір програмного забезпечення для введення електронного документообігу за сукупністю тих критерї̈в, що задовольняють його задачам автоматизачії.

Наведено детальний опис формалізованого алгоритму життєвого ииклу управлінського рішення в системах електронного документообігу України. Завдяки використанню таких алгоритмів на старті проектів впровадження у підприємства-замовника забезпечується чітке представлення про сутність процесів автоматизації, що, відповідно, зменшує ризики проекту.

Ключові слова: системи електронного документообігу, управління інформаційними ресурсами, управління процесами, критерії вибору.

\section{Introduction}

The economic activity of a modern enterprise takes place under conditions of many factors of influence and requires prompt acceptance and approval of justified management decisions. This is possible only by automating all links and structures of the enterprise. At the same time, the tasks of electronic communication between employees of the enterprise, the tasks of control and analysis of the performing discipline become more urgent. Ukrainian companies already understand that automation of records management, document management, process management at the enterprise will not only facilitate, systematize and make work of their employees transparent, but also provide tangible economic benefits.

For the successful launch of any automation project today, three key components are needed:

- understanding of current trends and trends in the market of providing automation services;

- possession of the criteria for a full and comprehensive assessment of automation tools to select the optimal criteria for the combination, meet the automation of the enterprise;

- formalization of business processes of the enterprise their information to a set of steps (stages), which can be described by means of algorithmization.
Despite a large number of publications in the field of e-document circulation, the answer to these three questions for the sector of document management in Ukraine has not been fully and comprehensively disclosed. And what is especially important for the purposes of implementation practice, the criteria for choosing document management automation systems are not systematized and not coordinated with modern development trends. In addition, the modern process approach in e-document management systems (EDMS) requires the customer to clearly represent the essence of automation processes, which necessitates the formalization of basic processes.

Thus, the tasks of researching current trends in the Ukrainian EDMS market, systematization of the criteria for evaluating and selecting systems that meet development trends and the description of formalized algorithms for key processes of e-document management are relevant in the conditions of the Ukrainian IT market.

\section{The object of research and its technological audit}

The object of research is the selection criteria for the EDMS system in the IT market of Ukraine and the life cycle of the management decision in the EDMS. 
For the customer and the user of the system that is directly for the subjects of the EDMS market, it is important to choose the software and its further support, largely determines the success of the automation project. There are a lot of different offers on the Ukrainian market today from Ukrainian, Russian and world vendors. In addition, the incredibly high pace of development of the IT industry complicates the task of choice, since it is necessary to take into account not only the requirements of the modern day, but also the prospective trends and trends of the industry.

As the practice of EDMS implementation in Ukraine shows, as a rule, every time the project team of the enterprise begins to restore its system of evaluation criteria, losing for this time, funds and rarely based on the experience of previous researchers. In order to navigate the selection and take into account all the criteria in a comprehensive manner, in accordance with the EDMS of the Ukrainian market and the world development trends, it is necessary to have a unified balanced system of EDMS evaluation indicators. The availability of such system will provide an opportunity to analyze existing EDMSs and effectively select from them exactly those that are most relevant to automation tasks at each particular enterprise.

One of the key areas of modern e-document management is the shift of emphasis directly from documents to the processes of their processing. In complex automation systems, the basic process is the process of processing management decisions. And understanding the algorithm for coordinating management decisions at the enterprise and the essence of its stages from the point of view of e-document management is a necessary component of the automation process. It is very important for the customer and the executor of the project to implement the EDMS in single terms and on a single entity. For this, it is necessary to have a formalized representation of the life cycle algorithm of the management solution in the enterprise and to understand the features of its processing at each stage of the cycle.

\section{The aim and objectives of research}

The aim of research is improvement of the process of implementing e-document management systems and process management in Ukraine.

The following research objectives are determined:

1. Analysis of the features of the introduction and trends in the development of e-document management systems in the Ukrainian market.

2. Forming and systematization of effective criteria for choosing a document management automation system in accordance with modern trends in the EDMS development and Ukrainian state standards.

3. Description of the formalized algorithm for the life cycle of the management solution in e-document management systems in Ukraine.

\section{Research of existing solutions of the problem}

The analysis of e-document management systems in the world and Ukrainian IT-markets is conducted in [1-5]. According to Gartner and IDS in recent years, significant globalization and mergers of a number of companies took place on the ECM (Enterprise Content Management) market of large Western players. Today, the three leaders include IBM Corporation (United States) (combining the lines of FileNet products and IBM Content Manager), Open Text Corporation (Canada) (Hummingbird Enterprise, Open Text Livelink ECM and IXOS) and EMC (Documentum and EMC). According to the latest relevant data in the report of Global Market Insights, Inc. [4] the influential manufacturers in this market have added new companies. These are Xerox (USA), Canon Inc. and Ricoh Company Ltd. (Japan), eFileCabinet Inc. (USA), SpringCM (USA), Oracle (USA), Alfresco Software Inc. (United Kingdom) and Hyland Software Inc. (USA).

In [5-7], enterprise-class systems on the European market in 2018 were investigated with basic criteria, among which:

- document processing and integration tools;

- security;

- work in the cloud and from mobile devices;

- ease of tracking work processes and the like.

The highest rating for the set of criteria was scored software products Ascensio System OnlyOffice, Microsoft SharePoint Online and DocuWare Cloud [3].

In work [4] it is noted that according to forecasts the world market of e-document circulation from 2017 to 2023 will increase from 3.59 billion USD to 6.32 billion USD. At the same time, the share of the European market in this sphere is assumed at the level of $33 \%$.

In works [2, 8-10] considerable attention is divided in the EDMS development in Ukraine. The rapid growth of these technologies is attributed to the 2005, and the beginning of the industrial operation is in 2008. For today in Ukraine the serious basis for fast and effective introduction of the automated systems in this area is prepared. First of all, this is a significant European experience in the use of e-document management systems and has been formed in recent years by the legislative platform. The latter include laws: «On Electronic Documents and Electronic Document Management» [11], «On Electronic Digital Signature», «On the Mandatory Copy of Documents», «On the National Informatization Program», «On Electronic Commerce», «On Information Security in Information and Telecommunication Systems», etc.

In the Ukrainian IT market, EDMSs are represented by: FossDoc, e-Docs, Atlas DOC, Megapolis.DocNet, ASKOD, MLC. PROF. Today, they can add a new software product, BAS Document Management, CORP, which only enters the Ukrainian market, but confidently positions itself as an EDMS-class system and belongs to the line of Business Automation Software. According to the research [1] for 2008-2010 the ratio of implementations in commercial and government structures was approximately $70 \%$ by $30 \%$. The main potential customers of this software include the banking sector, the insurance industry and state and municipal authorities.

In work [8] the following indicators of the evaluation of the effect of introduction of SED in large retail chains of Ukraine are given:

- time for acceptance of goods is reduced by $60 \%$;

- fulfillment of the order to the suppliers is guaranteed

by $99 \%$;

- errors of manual input are excluded.

In addition, it is emphasized that a significant factor for the «introduction» of these systems is the reduction of the corruption component by excluding the services of 
«intermediaries» that affect the speed of decision-making and their outcome.

The majority of researchers of the Ukrainian market for document management systems note that unlike the world and European, this segment of the IT industry market has remained poorly researched and information-unsaturated. Data on volumes and capacity of the market are very approximate and are determined, as a rule, on the basis of assessments of the market participants themselves. As noted in [2], there is a significant need for segmentation of this market and in the systematization of the EDMS vendors and companies involved in the implementation.

It should be noted that practically all of the above studies are concerned, to varying degrees, with the evaluation and selection of the EDMS, but there is no single system for selecting evaluation criteria. Each author uses his own set of criteria that need to be constantly updated in accordance with new market needs and trends in the development of the IT sector. In addition, the Ukrainian EDMS market has its own specifics, leads to the need to take it into account when forming the criteria for selecting software to automate the domestic workflow and the processes of processing managerial decisions. To solve these problems, in turn, it is necessary to investigate the current trends and features of the development of e-document management systems in Ukraine.

\section{Methods of research}

Depending on the direction of the research tasks, the following methods of scientific research are used:

- scientific abstraction (in the formation of the goal, objectives and conclusions of research);

- bibliographic, monographic, comparative and synthetically analytical (in the process of processing and analysis of materials from literature sources on EDMS, ECM, BPM-systems in the world and Ukrainian ITmarkets);

- method of logical generalization and systematization (in the generalization of trends in the development of e-document management systems and the formation of basic criteria for their evaluation);

- algorithmic and graphical (when creating a formalized algorithm of the life cycle of the administrative decision in the EDMS).

\section{Research results}

In accordance with the objectives of research, let's describe the world and Ukrainian trends in the development of e-document management systems, based on which formulate the main criteria for assessing and selecting the automation system for document management and management solutions for a modern domestic enterprise.

6.1. The world tendencies of the EDMS. World trends in the development of e-document management systems can be divided into two main areas: expansion of functionality and technological development.

In the areas of expansion of functionality, let's note the following main trends:

- expansion of the processed documents. Internal documents are increasingly added to external document management (invoices, payment documents, bills, etc.). Today, unstructured and weakly structured documents (contracts, powers of attorney, technical and legal documentation, correspondence, etc.) fall into the sphere of e-document circulation;

- easy integration with external systems (ERP, CRM, Internet banking, etc.);

- implementation of workflow technology for application integration and business process automation;

- growth in demand for ECM class systems (Enterprise Content Management).

The main current trends in technological development include:

- transition from integration through APIs to integration through Web services based on the transmission of XML messages;

- expanding the use of methods of stream scanning and document recognition, the use of barcoding (due to the growth of system scalability and the increase in the types of documentation, are processed);

- cloud technology and the availability of SaaS-solutions,

which allows to work with the system as a service;

- mobile access functionality (mobile workplaces using tablets and smartphones).

6.2. Tendencies of the EDMS market in Ukraine. Undoubtedly, for the Ukrainian market the most interesting are their own developments, and this is due not only to the need to develop the Ukrainian IT sector, but also by objective factors such as product development directly under Ukrainian state standards and the competitive cost of such software. But today, Ukrainian development is not very much, and their functionality and other parameters are still much inferior to world competitors. The Ukrainian EDMS is winning the competition, as a rule, in the field of automation of state industrial structures, where specialized systems with rigidly defined logic of work are in demand.

Considering the general growth rates of the IT industry and very high rates of product development from the world's vendors in the industry, Ukrainian developers need to focus on a high level of competition. On the other hand, Ukraine has not yet begun the process of consolidation and merger of large «players» and there are opportunities for the appearance of new developers on the market.

An obligatory requirement for Ukrainian e-document management systems is the use of electronic digital signature (EDS) from accredited domestic centers and related, but much broader issues of information protection.

Increasingly, there are tasks of complex automation that go beyond the scope of the usual workflow in the direction of Document Management and Business Process Management (BPM) [13]. BPM-class systems are not yet represented in Ukraine in a large scale and in this direction some of the market participants see the priority perspective of their development [2, 12]. This, in turn, sets the tasks of integration with other business management systems of the enterprise. The concept of «seamless integration», which provides for the possibility of a user-friendly transition from one information system to another, when running a particular business process, becomes popular.

Based on the analysis of publication materials [6, 10, 14-16] and the above tendencies and peculiarities of the EDMS development in Ukraine, the main criteria for their evaluation and selection are systematized. There are six basic groups of criteria, shown in Fig. 1. 


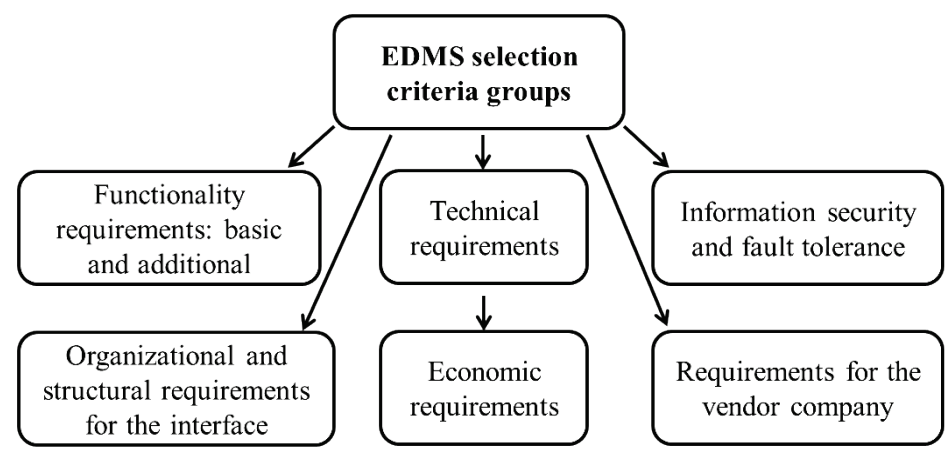

Fig. 1. Groups of criteria for selecting e-document management systems on the Ukrainian market

Each group is represented by its set of criteria, integrating the basic requirements of the modern IT industry and the features of implementation that are characteristic of the Ukrainian market.

1. Functionality requirements:

1.1. Main functionality:

- classical office work;

- general workflow;

- management of contractual activities;

- e-archive:

- accounting of working hours;

- work with citizens' appeals;

- project management;

- process management;

- work with the documentation of the quality management subsystem (see the basic principles and concept of the subsystem functioning in [17]);

- EDMS support from accredited domestic centers.

1.2. Additional functionality:

- mechanisms for working with files;

- recording of events and tools for booking time and premises;

- control of execution of instructions;

- presence of a system of reminders;

- availability of effective search tools;

- versioning of documents;

- bar-coding of printed documents;

- availability of graphic tools for processing analytical reports.

2. Technical requirements:

- support for various database management systems (DBMS) and cross-platform;

- support for all types of client sites: thick, thin and web; - open source code for offline development and support, flexibility of settings;

- multiview;

- integration with external systems (ERP, CRM, Internet banking, office programs, etc.) through a documented API or Web services;

- ensuring the necessary level of speed and scalability;

- possibility of organizing a distributed information base;

- mechanisms of work on mobile devices.

3. Information security and fault tolerance:

- availability of authentication mechanisms;

- EDS support;

- access rights management;

- mechanisms for backup and scheduled archiving;

- audit of all user actions and the ability to quickly search in the $\log$ of actions registration.
4. Economic requirements:

- low cost of ownership (purchase, implementation and support);

- quick return on investment;

- low payback period (from 2 to 3 years);

- minimization of the implementation period.

5. Organizational and structural requirements and requirements for the interface:

- full compliance with the legislation of Ukraine;

- Ukrainian-language interface and reference information;

- completeness of the reference information and the possibility of its prompt updating;

- flexibility of settings, customization;

- user-friendly interface (understood the construction of reference information);

- availability of built-in mechanisms for checking Ukrainian spelling;

- demonstration or remote access to the demobase.

6. Requirements for the vendor company:

- implementation methodologies that have been tested

in real projects;

- availability of information support;

- wide network of partners with many years of experience in implementation;

- prevalence of software of this brand in the professional market.

The expected functionality of ECM and BPM-systems assumes work not so much with the document as with the process of its processing, with processing rather not as an analog of a paper document, but as a specific management solution (MS). Therefore, it is very important from the point of view of automation to understand the algorithm for reproducing the life cycle of the management solution (Fig. 2) and the features of the implementation of each stage.

For enterprise employees, processes look like tasks, and the information system allows to handle these tasks:

- have an up-to-date list of all tasks;

- store all necessary information related to the task;

- manage the processes of task execution (task accep-

tance for processing, task forwarding, postponement of tasks, work with questions and clarification of tasks);

- correctly organize the process of performing tasks.

The stage of preparation of the management decision provides for the possibility of organizing events and working with internal documents. This, in turn, may require the system not only direct process control tools, but also additional functionality. This includes the ability to work with the system of events (meetings, meetings, protocols, control), the subsystem of working with files, the possibility of organizing forums, booking time and negotiation, the availability of own and shared calendars and the like. In turn, the organization of the implementation of management decisions in modern conditions often involves project work and thus requires the system to implement project accounting and control.

An unconditional link in the life cycle of a management decision is the control of execution. Monitoring should be carried out both promptly (in the process of work) and reduced (based on the results of work). In the operational version, individual objects of the system (documents, tasks, activities, etc.) are monitored and such parameters are monitored: controller, controlled, control period.

Consolidated control of all tasks the controller, usually gets through the system of built-in reporting. 


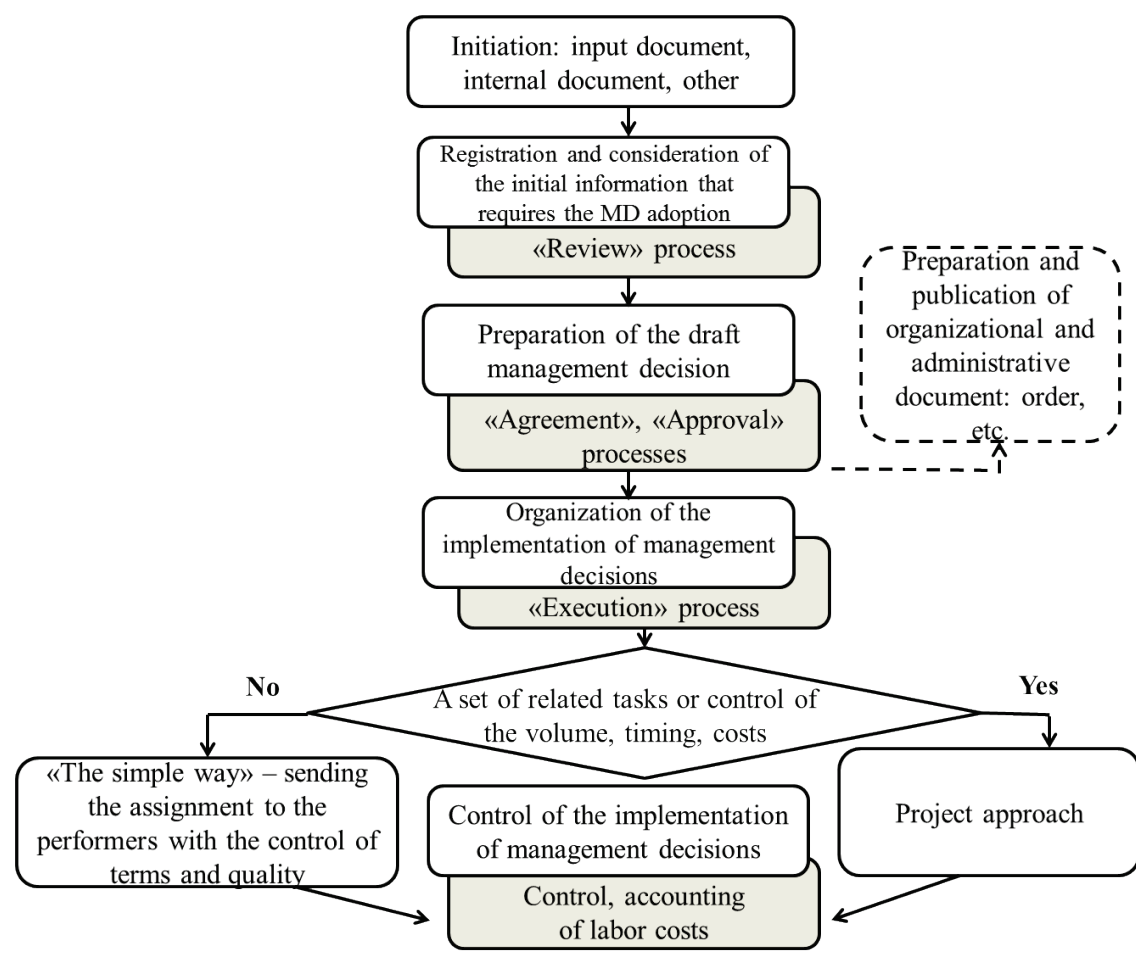

Fig. 2. Algorithm of the management decision life cycle

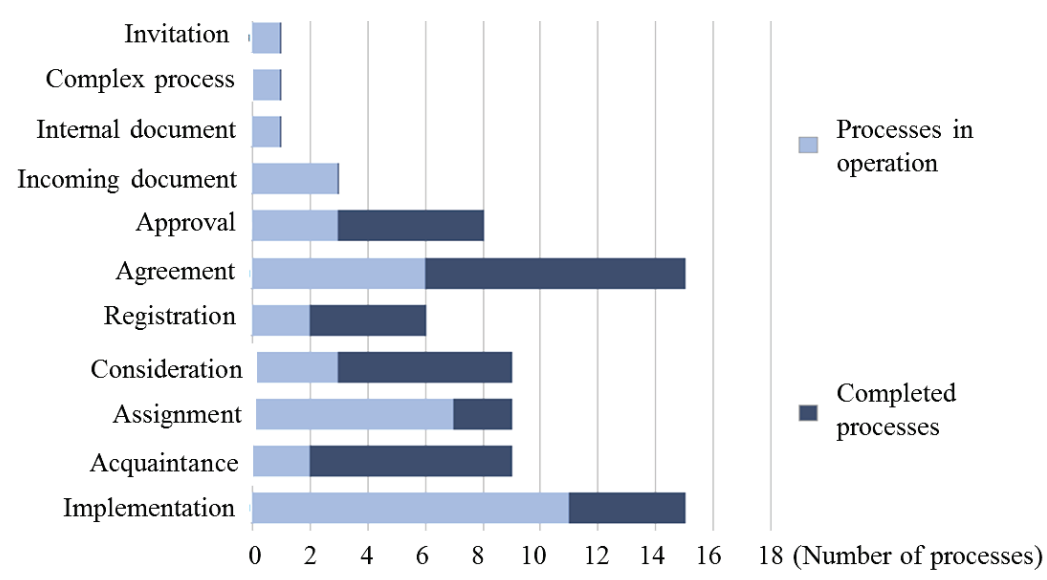

Fig. 3. The report on monitoring the state of business processes

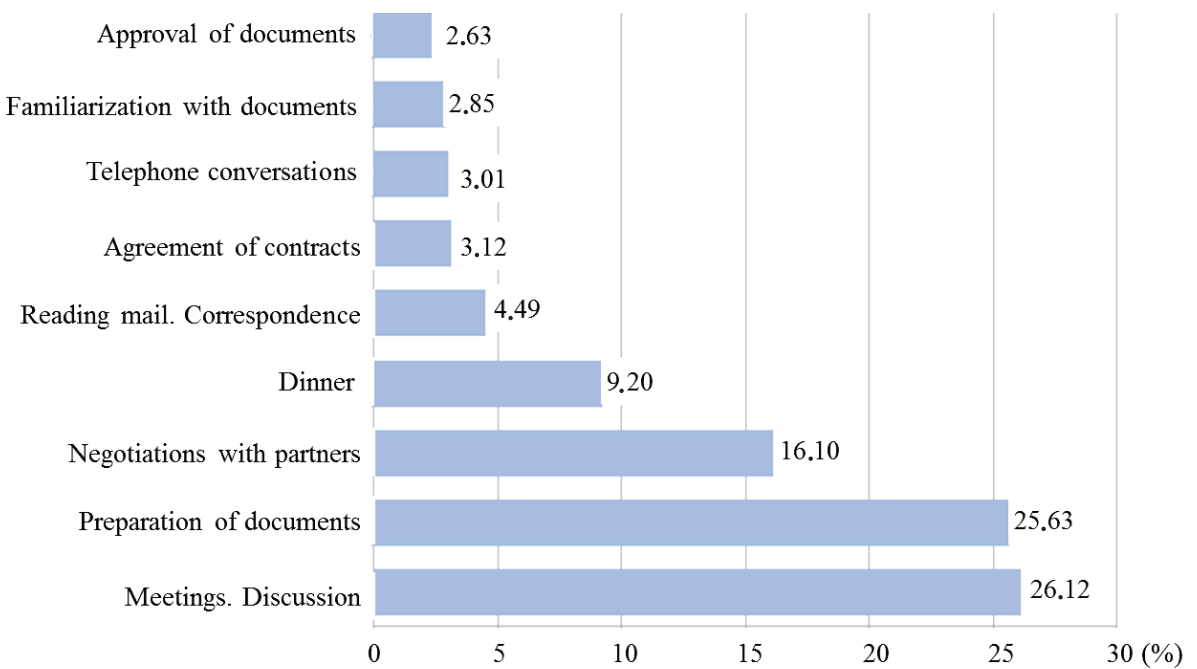

Fig. 4. The report of the control of time distribution for performance of process tasks
Fig. 3, 4 show examples of reporting types for data control regarding processes and process tasks. The report on monitoring the state of business processes (Fig. 3) provides statistical data on the types of processes. The report allows to analyze how many processes of each species in the specified period are in work, and which is completed. The time control report (Fig. 4) lists the top 10 most time-consuming types of work. This diagram allows to analyze the percentage of time spent by type of work and identify the work for which the most time is spent.

The composition and format of reporting in the field of document management in each EDMS is usually already defined at the level of its standard configuration. Customization and finalization of new forms of reporting to customer requirements are always possible, but their cost depends on such technical requirements to the system: open source code for offline revision and flexibility of settings. 


\section{SWOT analysis of research results}

Strengths. The results of the conducted research allow us to objectively assess the current state of the world and Ukrainian market of e-document management systems and the main perspective directions of its development. The criteria for choosing a document management automation system are systematized and allow the customer to clearly audit all requirements for the automation system that the modern market offers and choose from them those that are relevant to the tasks of automating his own business. The developed algorithm for processing the management solution will provide Ukrainian customers with a clear idea of the essence of process control already at the start of the automation project. All this in aggregate will allow to reduce the term of the project of implementation, the cost of initial research and, as a result, to receive the e-document system, which maximally satisfies the task of automation.

Weaknesses. Undoubtedly, the conducted research is not a static result, since the pace of development of IT-technologies requires constant updating of almost all results in this area, which leads to the need to update the evaluation criteria for information systems. This does not apply to the general algorithms of information processing, they are proven practice and the principles of working with them are unified for virtually all systems.

Opportunities. Let's note that, according to the current trends in the development of the Ukrainian IT-market, a promising direction is to conduct similar studies in the field of corporate resource management systems.

Threats. The statistical data on the implementation projects of the EDMS for Ukraine are more comprehensive and justified in 2012-2014. In recent years, systematic research has not been carried out in this area, and almost all information is based on an analysis of individual projects of implementation by participants of these projects (either on the part of the customer or on the part of companies involved in automation). But these publications are of a discrete nature and may not cover all aspects of automation processes. Therefore, the current trends in the development of Ukrainian EDMS may not take into account some of the trends, possibly in the near future.

\section{Conclusions}

1. The main global trends in the development of edocument management systems and the current trends in the development of these systems in Ukraine are studied and formulated. From the point of view of expanding functionality, the main trends include expanding the range of processed documents, increasing demand for ECM-class systems, focusing on the concept of process management, providing integration tools with ERP, CRM, etc. On the other hand, technology development requires the presence of SaaS solutions, mobile access, streaming scanning and bar-coding tools, support for digital signatures, and increased requirements for information security tools.

2. Six groups of basic criteria for EDMS evaluation and selection are systematized and formed: functional, technical, economic, organizational and structural requirements and interface requirements, requirements for information security and fault tolerance, requirements for the vendor company. For each category, a list of basic criteria has been compiled on which competitive software products for automation can be compared. These criteria correspond to modern standards and tendencies of development of the IT market and take into account the national specifics. The enterprise-customer can choose the entire list as a template for comparative analysis of competitive systems or choose from the criteria of each category those that most closely match its business objectives.

3. The paper presents a formalized algorithm for the life cycle of an administrative solution in e-document management systems in Ukraine. It describes how each stage of the algorithm looks from the point of view of the employees of the enterprise-customer and the requirements to the system ensure the qualitative performance of the tasks of the stage. Understanding the customer of this algorithm and the features of its implementation at the start of the project of implementing the e-document management system will reduce the risks and duration of the project and eventually get an efficiently functioning e-document management system.

\section{References}

1. Glinskikh A. Mirovoy rynok sistem elektronnogo dokumentooborota // Jet Info. Informatsionnyy byulleten. 2002. No. 8 (111). P. 40

2. Tabakov D. Elektronnyy dokumentooborot: mirovoy i ukrainskiy rynok // hi-Tech.ua. 02.06.2008. URL: https://hi-tech.ua/article/ elektronnyiy-dokumentooborot-mirovoy-i-ukrainskiy-ryinok/

3. Ferrill T. The Best Document Management Software of 2018 // PC Magazine. 2018. URL: https://www.pcmag.com/article2/ $0,2817,2490969,00$.asp

4. Document Management Systems Market by Offering (Solutions, Services), Deployment Mode (On-Premise, Cloud-Based, and Hybrid), Organization (Small \& Medium-Sized Enterprise, Large Enterprise), Application, and Geography - Global Forecast to 2023 // Research and Markets. December 2017. URL: https:// www.researchandmarkets.com/reports/4433681/document-management-systems-market-by-offering\#sample

5. Fearn N., McCaskill S. The best document management software of 2018 // TechRadar. 2018. URL: https://www.techradar.com/ news/top-5-best-document-management-systems

6. Horovoi O. Vybir systemy elektronnoho dokumentoobihu. URL https://fossdoc.com/ru/vybor-sed

7. Austerberry D. Digital Asset Management. CRC Press, 2013. P. 30. URL: https://books.google.com.ua/books?id=c5ncAwAA QBAJ\&pg $=$ PT38\&redir_esc $=y \#_{\mathrm{v}}=$ onepage $\& \mathrm{q} \& \mathrm{f}=$ false

8. Moroz V. Perspektyvy rozvytku elektronnoho dokumentoobihu // KyivStar Business Hab. 2015. URL: https://hub.kyivstar. ua/perspektivy-razvitiya-elektronnogo-dokumentooborota

9. Buryak V. Tendentsii na ukrainskom rynke elektronnogo dokumentooborota v 2017 godu // HiTech.Expert. 10.10.2017. URL: http://expert.com.ua/112063-tendencii-na-ukrainskomrynke-elektronnogo-dokumentooborota-v-2017-godu.html

10. Svistunov V. Metodika vybora optimal'noy SED - nash opyt. URL: http://itdirector.org.ua/Bullet_VOO/Statji/index.php?article=913

11. Pro elektronni dokumenty ta elektronnyi dokumentoobih: Law of Ukraine No. 851-IV from 22.05.2003// Vidomosti Verkhovnoi Rady Ukrainy. 2003. No. 36. Art. 275. URL: http:// zakon3.rada.gov.ua/laws/show/851-15

12. Kolesov A. Rynok SED/ESM: itogi-2012 i perspektivy-2013 // PCWeek. 2013. URL: https://www.itweek.ru/ecm/article/detail. php?ID=147015

13. Amiridi Yu., Ivanova N. Vnedrenie VRM-sistem: mirovye tendentsii i otechestvennyy opyt // Bankovskie tekhnologii. 2006. No. 4. URL: http://iso.ru/ru/press-center/publications/1451. phtml

14. Konyushenko E. K. Vybor sistemy elektronnogo dokumentooborota: vzglyad zakazchika // Obzornye stat'i. 2012. URL: http://www.iteam.ru/publications/it/section 64/article 2986/

15. Mokeeva T. Trudnosti elektronnogo dokumentooborota // Seriya prakticheskikh statey. 2012. URL: http://www.klerk.ru/buh/ articles/313946/ 
16. Bobyleva M. P. Razvitie printsipov dokumentooborota pri perekhode ot bumazhnogo k elektronnomu vzaimodeystviyu // Deloproizvodstvo. 2012. No. 2. URL: http://www.top-personal.ru/ officeworkissue.html?224

17. Tetrvak D. Dokumentatsiya sistemy kachestva. Komu ona nuzhna? 2008. URL: http://www.businessstudio.com.ua/info/articles. php?ELEMENT ID=11430
Chaikovska Olena, PhD, Associate Professor, Head of the Department of Computer Sciences, Kyiv University of Culture and Arts, Ukraine, e-mail: lena@knukim.edu.ua, ORCID: https://orcid.org/ 0000-0001-7769-1004

Stolyarchuk Irina, PhD, Senior Lecturer, Department of Computer Sciences, Kyiv University of Culture and Arts, Ukraine, e-mail irina77st@gmail.com, ORCID: https://orcid.org/0000-0002-2536-6696

\section{Kovtun T., DEVELOPMENT OF METHODICAL Smokova T. APPROACH TO THE ANALYSIS OF INTEGRATION RISKS IN THE PROJECT OF CREATION OF THE LOGISTICS CENTER}

Об'єктом дослідження є проект логістичного центру, який розглядається як організаційно та виробничо інтегрована складна система, основним завданням якої є забезпечення умов для інтегращії різноманітних об’єктів логістичної та супутньої інфраструктури на одній території. Це надає можливість поліпшення переміщення логістичних потоків.

Одним з найбільших проблемних місць є відсутність проектно-орієнтованого підходу при створенні логістичного иентру, який характеризується великою кількістю учасників, що змінюється на протязі його життєвого циклу. Це призводить до виникнення інтеграційних проектних ризиків, для запобігання яких необхідно розробити підхід до якісного аналізу ризиків, що враховує специфічні особливості об'єкту дослідження.

В ході дослідження визначено поняття «інтеграційного проектного ризику». А також розроблено послідовність якісного аналізу інтеграційних ризиків в проекті створення логістичного центру, яка полягає у використанні методів менеджменту якості, а саме: аналізу Парето, $A B C$-аналізу та причинно-наслідкового аналізу Ісікави. Застосування методів якісного аналізу здійснюється у логічній послідовності. Вихідні дані, що отримані при проведенні попереднвого виду аналізу, є вхідними для наступного етапу дослідження.

Отримані результати якісного аналізу ризику дозволяють на початковій стадії проекту збільшити вплив на його результати завдяки зниженню ступеню інтеграційних ризиків. Зокрема, аналіз Парето пропонується використовувати для виявлення основних причин виникнення інтегращійних ризиків проекту створення логістичного центту. АВС-аналіз дозволяє виділити учасників проекту, що мають найбільшу кількість інтеграційних зв'язків. Отже вихід такого учасника з проекту принесе найбільші порушення інтеграції між елементами системи. Причинно-наслідковий аналіз Ісікави дозволяє виявити причини розриву інтеграційних зв'язків між учасниками проекту та визначити найменш потужні інтеграційні зв'язки між учасниками.

Отже, використання запропонованої послідовності якісного аналізу дозволить виявити учасників проекту, які найбільш уразливі до впливу інтеграчійних ризиків та визначити потужність інтеграційних зв'язків між ними. Це, в свою чергу, дозволить прийняти заходи для попередження настання інтеграчійних ризиків у проекті створення логістичного центру.

Ключові слова: проект створення логістичного центру, інтеграційні ризики, якісний аналіз ризиків проекту.

\section{Introduction}

The state of the transport system is one of the indicators of the overall development of the country's economic complex, because transport, as an infrastructure branch, should evolve at rates that are ahead of other sectors of the economy and contribute fast economic and social growth in the country. The transport industry of Ukraine should meet the needs of internal, export-import transportation, the volume of which is determined by the level of development of the country's economy. In addition, Ukraine has always been one of the main transit states on the European continent, through which the general transport paths passed at all times. At present, the following international transport corridors (ITC) pass through the territory of Ukraine [1]:

- Cretan ITC No. 3: Berlin (Dresden) - Wroclaw Lviv - Kyiv;

- Cretan ITC No. 5: Venice - Trieste - Ljubljana Budapest - Bratislava - Uzhgorod - Lviv;

- Cretan ITC No. 9: Helsinki - St. Petersburg/Moscow - Kyiv - Chisinau - Bucharest - Alexandroupolis; - Europe - Asia;

- Gdansk - Odessa (the Baltic Sea - the Black Sea);

- Europe - Caucasus - Asia (TRACECA);

- ITC of the Black Sea Economic Cooperation. 